\title{
Pulse and direct current electrodeposition of zinc oxide layers for solar cells with extra thin absorbers
}

\author{
G. Khrypunov ${ }^{1,{ }^{*}}$, N. Klochko ${ }^{1}$, N. Volkova ${ }^{2}$, V. Kopach ${ }^{1}$, V. Lyubov ${ }^{1}$, K. Klepikova ${ }^{1}$ \\ ${ }^{I}$ National Technical University "Kharkiv Polytechnic Institute", Kharkiv, Ukraine \\ ${ }^{2}$ National Aerospace University "Kharkiv Aviation Institute", Kharkiv, Ukraine \\ *Corresponding author.Tel: +380-572-971928,E-mail: khrip@ukr.net
}

\begin{abstract}
The feasibility of one-dimensional (1D) nanostructured zinc oxide array pulse plating has been presented. An effect of the electrolyte composition, deposition regime and subsequent annealing on structure and optical properties of the electrodeposited $\mathrm{ZnO}$ layers has been approved by X-ray diffraction and spectrophotometric analysis. We have determined that for obtaining of $\mathrm{ZnO}$ arrays with strong (002) preferable growth orientation in the c-axis direction it is necessary to diminish adsorption of hydrogen and $\mathrm{Cl}^{-}$-ions. It has been shown that such conditions are created in electrolyte that contains $0.05 \mathrm{M} \mathrm{Zn}\left(\mathrm{NO}_{3}\right)_{2}$ and $0.1 \mathrm{M} \mathrm{NaNO}_{3}$ during electrodeposition on FTO-coated glass substrates in pulse plating regime with rectangular impulses of cathode potential $\left(20 \mathrm{~ms}\right.$ on-time at $U_{\text {on }}=-1.4 \mathrm{~V}$ and $30 \mathrm{~ms}$ off-time at $U_{\text {off }}=-0.8 \mathrm{~V}$ ). Therefore, in this work we for the first time have demonstrated the successful growth of $1 \mathrm{D} \mathrm{ZnO}$ nanostructures by pulse plating without using of templates. The novel electrodeposition technique gives possibilities for the manufacture of the $\mathrm{ZnO}$ arrays suitable for solar cells with extra thin absorbers.
\end{abstract}

Keywords: Electrodeposition, Zinc oxide, Pulse plating

\section{Introduction}

Zinc oxide $(\mathrm{ZnO})$ has attracted a lot of research interest in recent years due to its unique optical and electronic properties and low cost of materials and fabrication. A wide variety of $\mathrm{ZnO}$ crystallite morphologies are observed for both precipitates and thin films including columnar grains, rods, stars and spherical habits [1-4]. Now highly transparent conducting $\mathrm{ZnO}$ windows are important components of photovoltaic devices and displays. Recently, solar cells with extra thin absorbers (ETA SC) have shown high potential of $\mathrm{ZnO}$ arrays as semiconductor covered electrodes and dye-sensitized photoanodes, particularly, $\mathrm{ZnO}$ nanorods proved to be suitable for application in organic photovoltaic devices $[5,6]$. An assortment of $\mathrm{ZnO}$ nanostructures, such as whiskers, nanowires, nanorods, nanotubes, nanorings and nano-tetrapods have been successfully grown via a variety of methods including chemical vapor deposition, thermal evaporation, and electrodeposition. But despite numerous studies, there is little understanding of the mechanisms and factors that govern the observed morphology [1]. Among other deposition techniques electrodeposition has various advantages, viz. low processing cost, large scale, no vacuum system need, high deposition speed and no use of toxic gases. Effects of electrolyte formula, namely anionic composition [4] and presence of the different organic additives [6], deposition temperature and deposition time [7] and even gravitational level effects [9] on structure and properties of the electrodeposited ZnO nanowire arrays are studied extensively. Nevertheless, there are only rare attempts to employ a pulsed potential technique for $\mathrm{ZnO}$ electrodeposition [10]. On the same time, the use of pulse plating is well-known promising way to perfect properties of the electrodeposited layers. That's why purpose of this work is a comparative study of influence of direct current and pulse plating conditions, electrolyte composition and subsequent air annealing on $\mathrm{ZnO}$ film structure and optical properties in order to reveal means for obtaining of one-dimensional (1D) zinc oxide nanostructured layers applicable for ETA SC. 


\section{Methodology}

$\mathrm{ZnO}$ arrays were electrodeposited on transparent indium tin oxide (ITO) or fluorine doped tin oxide (FTO) covered glass (Pilkington) cathodes in aqueous electrolytes contained $\mathrm{ZnSO}_{4}$ or $\mathrm{Zn}\left(\mathrm{NO}_{3}\right)_{2}, \mathrm{KCl}$ and $\mathrm{NaNO}_{3}$ (Table 1) in three-electrode cell with platinum counter-electrode and saturated $\mathrm{Ag} / \mathrm{AgCl}$ reference electrode. Electrodeposition of each $\mathrm{ZnO}$ layer sample was carried out during 1 hour at $70{ }^{\circ} \mathrm{C}$ under potentiostatic conditions (at constant cathode potential $\mathrm{U}$ ) or under pulse plating regimes with rectangular impulses of cathode potential (20 ms on-time at $U_{\text {on }}$ and 30 ms off-time at $U_{\text {off }}$ ). All potential values in Table 1 are given versus saturated $\mathrm{Ag} / \mathrm{AgCl}$ reference electrode. In some experiments electrolyte was magnetically stirred (marked + in Table 1). A following treatment of some $\mathrm{ZnO}$ layers was fulfilled by air annealing at $200{ }^{\circ} \mathrm{C}, 300{ }^{\circ} \mathrm{C}$ and $400{ }^{\circ} \mathrm{C}$ for 1 hour each.

Phase composition and structure of the deposited films were determined by XRD-method using an X-ray diffractometer DRON-4M with $\mathrm{CoK}_{\alpha}$ radiation according to $\theta-2 \theta$ - scheme. Preferable orientations of the films were researched by analytical treatment of the X-ray diffractions by means of obtaining of texture factor $P_{i}[11]$ :

$$
P_{i}=\frac{\left(I_{i} / I_{0 i}\right) \cdot N}{\sum_{1}^{N} I_{i} / I_{0 i}}
$$

where $I_{i}$ - experimental intensity of maximum; $I_{0 i}$ - intensity of this line in accordance with JCPDS card; $\mathrm{N}$ - total number of $\mathrm{X}$-ray reflections.

Angles $\varphi$ between texture axis and surface normal for all reflection planes and $\mathrm{P}_{\mathrm{i}}$ values have been calculated according to relation [11]:

$$
\cos \varphi=\frac{h h_{i}+k k_{i}+\frac{1}{2}\left(h k_{i}+h_{i} k\right)+\frac{3}{4} \frac{a^{2}}{c^{2}} l_{i} l}{\sqrt{h^{2}+k^{2}+h k+\frac{3}{4} \frac{a^{2}}{c^{2}} l^{2}} \sqrt{h_{i}^{2}+k_{i}^{2}+h_{i} k_{i}+\frac{3}{4} \frac{a^{2}}{c^{2}} l_{i}^{2}}}
$$

A shape of function $P=f(\varphi)$ allow [11] to distinguish degree of texture perfection: the texture is perfect if $P$ decreases rapidly. When the function $P=f(\varphi)$ has two or more vertexes, then the structure has two or some texture axes. Average crystalline sizes t (i. e. X-ray domains defined as volumes that diffract coherently) and lattice strains $\Delta \mathrm{d} / \mathrm{d}$ of the electrodeposited $\mathrm{ZnO}$ arrays were determined by the Williamson-Hall formula for adherent deposits [12]. ZnO lattice characteristics a and c were calculated using the formula [11]:

$$
\frac{1}{d^{2}}=\frac{4}{3} \frac{h^{2}+h k+k^{2}}{a^{2}}+\frac{l^{2}}{c^{2}}
$$


Table 1. Electrolytes and electrolysis regimes used for deposition of $\mathrm{ZnO}$.

\begin{tabular}{|c|c|c|c|c|c|c|c|c|}
\hline \multirow[t]{2}{*}{$\begin{array}{l}\text { Sample } \\
\text { number }\end{array}$} & \multirow[t]{2}{*}{ Electrolyte } & \multirow[t]{2}{*}{$\begin{array}{l}\text { Deposition } \\
\text { regime }\end{array}$} & \multicolumn{3}{|c|}{$\begin{array}{l}\text { Cathode } \\
\text { potential } \\
(\mathrm{V})\end{array}$} & \multirow[t]{2}{*}{$\begin{array}{l}\text { Magnetic } \\
\text { stirring }\end{array}$} & \multirow{2}{*}{$\begin{array}{c}\text { Current } \\
\text { density } \\
\mathrm{j} \\
\left(\mathrm{mA} / \mathrm{cm}^{2}\right)\end{array}$} & \multirow{2}{*}{$\begin{array}{l}\text { Charge- } \\
\text { area } \\
\text { ratio } \\
\mathrm{q}\left(\mathrm{C} / \mathrm{cm}^{2}\right)\end{array}$} \\
\hline & & & $\mathrm{U}$ & $\mathrm{U}_{\mathrm{of}}$ & $\mathrm{U}_{\text {on }}$ & & & \\
\hline 1 & $7 \cdot 10^{-4} \mathrm{M} \mathrm{ZnSO}_{4}$ & Potentiostat & C -1 & .3 & - & - & + & $2 \rightarrow 1.4$ \\
\hline \multicolumn{9}{|l|}{6.1} \\
\hline 2 & $0.1 \mathrm{M} \mathrm{KCl}$ & Pulse & - & -0.9 & -1.5 & + & $1.3 \rightarrow 0.5$ & 3.1 \\
\hline 3 & $0.05 \mathrm{M} \mathrm{NaNO}_{3}$ & Pulse & - & -1.0 & -1.6 & + & $2.6 \rightarrow 1.5$ & 5.4 \\
\hline 4 & $\begin{array}{c}\cdot 10^{-4} \mathrm{M} \mathrm{ZnSO}_{4} \\
0.1 \mathrm{M} \mathrm{KCl} \\
0.001 \mathrm{M} \mathrm{NaNO}_{3}\end{array}$ & Pulse & - & -0.9 & -1.5 & + & $0.6 \rightarrow 0.4$ & 1.4 \\
\hline 5 & $0.05 \mathrm{M} \mathrm{Zn}\left(\mathrm{NO}_{3}\right)_{2}$ & Potentiostatic & -1.1 & - & - & - & 1.1 & 4.0 \\
\hline 6 & $0.1 \mathrm{M} \mathrm{NaNO}_{3}$ & Pulse & & - & 0.8 & -1.4 & - & $0.5 \rightarrow 0.8$ \\
\hline
\end{tabular}

The transmittance spectra of $\mathrm{ZnO}$ layers were measured by double beam spectrophotometer SF-46 in the spectral range $0.4-0.9 \mu \mathrm{m}$, when the sample $\mathrm{ZnO} / \mathrm{FTO} / \mathrm{glass}$ was put into working canal and FTO/glass or ITO/glass one was placed in reference canal.

\section{Results}

As-electrodeposited films were high adherent, semitransparent and scattered visible light. Samples 1 and 2 were grayish in color, but others were white. Figure 1 shows the transmittance spectra (T vs. wavelength $\lambda$ ) for the as-grown and air annealed $\mathrm{ZnO}$ layers. As it can be seen, from the one side, the grayish layers increase their transmittance after the annealing (they became white, probably owing to oxidation of $\mathrm{Zn}$ traces). From the other side, according to transmittance data, irrespective of electrolyte stirring, sample 3 offers the thinnest near transparent film, samples 1, 2 and 4 were thicker, samples 5 and 6 (not presented in Fig. 1) were the thickest. Assuming $\mathrm{ZnO}$ to be typical direct band gap semiconductor, the corresponding optical band gap has been estimated by the zero-crossing of the rising edge of the $[(-\ln T) x h v]^{2}$ vs. hv curve [8] (Fig. 1, inset). All obtained band gap values as before such as after annealing correspond to $\mathrm{ZnO}\left(\mathrm{E}_{\mathrm{g}}\right.$ near $\left.3.2-3.3 \mathrm{eV}\right)[2,3,9]$.

Investigation of structure of zinc oxide arrays electrodeposited in electrolytes and regimes presented in Table 1 has shown (Fig. 2) that all diffraction peaks match the hexagonal structure of wurtzite $\mathrm{ZnO}$ (with the exception of reflections assigned to FTO-glass or ITOglass substrates). Comparative analysis of XRD patterns of the electrodeposited ZnO layers has revealed that, from the one side, the intensity of $\mathrm{ZnO}$ diffraction peaks is in direct proportion to concentration of $\mathrm{NO}_{3}{ }^{-}$-ions in the electrolyte that allows us to conclude that thicknesses of $\mathrm{ZnO}$ layers grow when amounts of nitrates increase.

From the other side, a deviation of cathode potential towards more negative values $(\mathrm{U}=-1.3$ $\mathrm{V}$ for electrodeposited in potentiostatic regime sample 1 and $20 \mathrm{~ms}$ on-time at $\mathrm{U}_{\text {on }}=-1.6 \mathrm{~V}$ and $30 \mathrm{~ms}$ off-time at $\mathrm{U}_{\text {off }}=-1.0 \mathrm{~V}$ for pulse plated sample 3) result in the obtaining of very thin near amorphous $\mathrm{ZnO}$ layers, in spite of their large current densities and charge-area ratios of the electrodeposition processes. To our opinion, the reason for that is a most probable intense additive cathode reaction of hydrogen generation in aqueous electrolytes for $\mathrm{ZnO}$ deposition that fulfilled at comparatively negative potentials according to relation [13]: 
$2 \mathrm{H}_{2} \mathrm{O}+2 \overline{\mathrm{e}} \rightarrow \mathrm{H}_{2} \uparrow+2 \mathrm{OH}^{-} \quad \mathrm{E}^{0}=-1.05 \mathrm{~V}$ vs. saturated $\mathrm{Ag} / \mathrm{AgCl}$
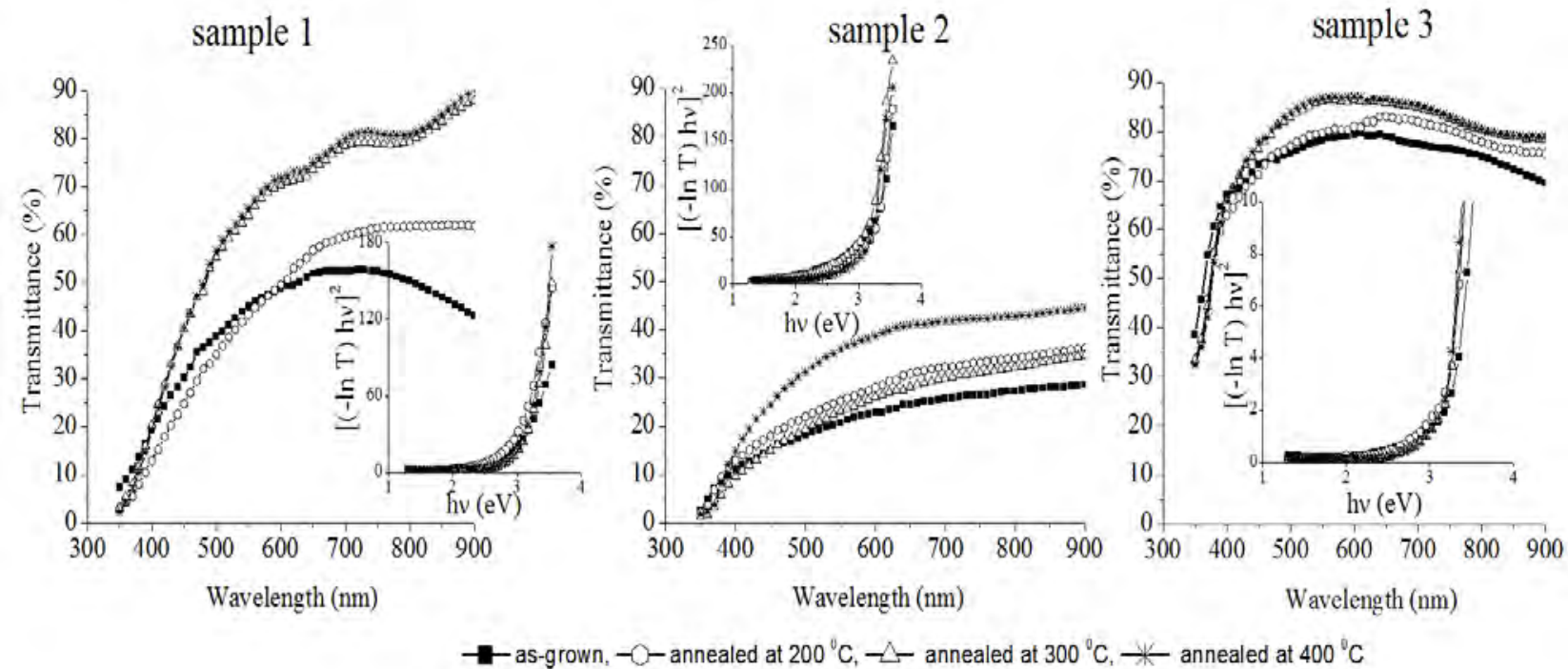

Fig. 1. O ptical transmittance spectra and the corresponding band gap spectra (insets) of aselectrodeposited and air annealed $\mathrm{ZnO}$ arrays.

Probably, hydrogen beads adsorbed on the surfaces of substrates or on the growing $\mathrm{ZnO}$ crystals suppress adsorption of $\mathrm{Zn}^{2+}$ and $\mathrm{OH}^{-}$-ions and therefore inhibit growth of zinc oxide arrays, which could be carried out as follows:

$\mathrm{Zn}^{2+}+2 \mathrm{OH}^{-} \rightarrow \mathrm{Zn}(\mathrm{OH})_{2} \rightarrow \mathrm{ZnO}+\mathrm{H}_{2} \mathrm{O}$

At less negative cathode potentials $(\mathrm{U}=-1.1 \mathrm{~V}$ for electrodeposited in potentiostatic regime sample 5 and $\mathrm{U}_{\text {on }}=-1.5 \mathrm{~V}$ and $\mathrm{U}_{\text {off }}=-0.9 \mathrm{~V}$ for pulse plated sample 2 and more clearly for sample 6 deposited in the pulse regime at $\mathrm{U}_{\text {on }}=-1.4 \mathrm{~V}$ and $\mathrm{U}_{\text {off }}=-0.8 \mathrm{~V}$ ) current efficiency of the $\mathrm{ZnO}$ electrodeposition process increases, that can be seen from comparison of overall intensities of $\mathrm{ZnO}$ diffraction peaks for this samples (Fig. 2) and their current densities and charge-area ratios (Table 1).

Required for acceleration of $\mathrm{ZnO}$ synthesis cathode reductions of nitrate-ions with creation of $\mathrm{OH}^{-}$- groups can be realized according to [13] as follows:

$$
\begin{array}{ll}
\mathrm{NO}_{3}{ }^{-}+\mathrm{H}_{2} \mathrm{O}+2 \overline{\mathrm{e}} \rightarrow \mathrm{NO}_{2}{ }^{-}+2 \mathrm{OH}^{-} & \mathrm{E}^{\mathrm{o}}=-0.21 \mathrm{~V} \text { vs. saturated Ag/AgCl } \\
\mathrm{NO}_{3}{ }^{-}+\mathrm{H}_{2} \mathrm{O}+\overline{\mathrm{e}} \rightarrow \mathrm{NO}_{2} \uparrow+2 \mathrm{OH}^{-} & \mathrm{E}^{\mathrm{o}}=-1.08 \mathrm{~V} \text { vs. saturated Ag/AgCl } \\
\mathrm{NO}_{3}{ }^{-}+2 \mathrm{H}_{2} \mathrm{O}+3 \overline{\mathrm{e}} \rightarrow \mathrm{NO} \uparrow+4 \mathrm{OH}^{-} & \mathrm{E}^{\mathrm{o}}=-0.36 \mathrm{~V} \text { vs. saturated Ag/AgCl} \\
\mathrm{NO}_{3}{ }^{-}+7 \mathrm{H}_{2} \mathrm{O}+8 \overline{\mathrm{e}} \rightarrow \mathrm{NH}_{4} \mathrm{OH}+9 \mathrm{OH}^{-} & \mathrm{E}^{\mathrm{o}}=-0.34 \mathrm{~V} \text { vs. saturated Ag/AgCl }
\end{array}
$$

To our opinion, the most useful for $\mathrm{ZnO}$ deposition is cathode reaction Eq. (6), because processes Eq. (7) and Eq. (8) produce gaseous compounds whose adsorption can suppress 
growth of $\mathrm{ZnO}$, and reaction Eq. (9) is undoubtedly sophisticated multistage process as such as it consumes eight electrons. Therefore, high amount of $\mathrm{NO}_{3}{ }^{-}$-ions is a cause of the elevated thicknesses of samples 5 and 6 . Enhanced structure of sample 2 as compared with sample 1 is evidently a result of such advantage of pulse electrolysis as suppression of additive cathode reaction Eq. (4), because it is impossible at $U_{\text {off }}$, but during off-time ions $\mathrm{NO}_{3}{ }^{-}$and $\mathrm{Zn}^{2+}$ can diffuse to the cathode and can be realized processes Eq. (6), Eq. (8) and Eq. (9) which are useful for creation of $\mathrm{ZnO}$.

Moreover, at on-time electrochemical reaction Eq. (7) and reduction of $\mathrm{Zn}^{2+}$ are doubtless:

$\mathrm{Zn}^{2+}+2 \overline{\mathrm{e}} \rightarrow \mathrm{Zn} \quad \mathrm{E}^{\mathrm{o}}=-0.98 \mathrm{~V}$ vs. saturated $\mathrm{Ag} / \mathrm{AgCl}$

So, during off-time internal electrolysis is additive possible way for creation of $\mathrm{ZnO}$ arrays through following heterogeneous chemical reaction:

$\mathrm{Zn}+\mathrm{NO}_{3}{ }^{-}+\mathrm{H}_{2} \mathrm{O} \rightarrow \mathrm{NO}_{2}^{-}+\mathrm{Zn}(\mathrm{OH})_{2}$

Table 2 shows structure characteristics of thicker $\mathrm{ZnO}$ layers. All $\mathrm{ZnO}$ arrays are nanostructured and characterized by little compressive stress (samples 2 and 5) or tension (sample 6). Lattice constants a are near value for single crystal $\mathrm{ZnO}$ of hexagonal modification, but the electrodeposited $\mathrm{ZnO}$ grains were elongated along $\mathrm{c}$ axis (according to JCPDS 36-1451, a = 3.250, $\mathrm{b}=5.207$ ).

Table 2. Structure characteristics of the electrodeposited $\mathrm{ZnO}$ arrays.

\begin{tabular}{|c|c|c|c|c|}
\hline \multirow[t]{2}{*}{ Sample number } & \multicolumn{2}{|c|}{$\begin{array}{c}\text { Lattice constant } \\
(\hat{\AA})\end{array}$} & \multirow[t]{2}{*}{$\begin{array}{l}\text { Average crystalline } \\
\text { size t }(\mathrm{nm})\end{array}$} & \multirow[t]{2}{*}{$\begin{array}{l}\text { Lattice strain } \\
\Delta \mathrm{d} / \mathrm{d} \times 10^{4}\end{array}$} \\
\hline & $\mathrm{a}$ & C & & \\
\hline 2 & 3.251 & 5.228 & 27 & 14.5 \\
\hline 5 & 3.249 & 5.226 & 54 & 3.5 \\
\hline 6 & 3.253 & 5.220 & 16 & -36.8 \\
\hline
\end{tabular}

Comparison of preferable orientations has revealed (Fig. 3) that ZnO layer prepared in electrolyte with low concentration of nitrates (sample 2) has crystallites with random orientation. There seems to be main reason for such structure that the polar (002) crystal plane of the $\mathrm{ZnO}$ is capped by $\mathrm{Cl}^{-}$-ions (from the $\mathrm{KCl}$ supporting electrolyte), which $[1,4]$ redirect the growth of $\mathrm{ZnO}$. Sample 5 plated at direct current in $\mathrm{NO}_{3}{ }^{-}$-enriched electrolyte has two preferable orientations (002) and (103), probably because of influence of cathode reaction of hydrogen evolution by Eq. (4). Only sample 6 electrodeposited in electrolyte, which contains large concentration of $\mathrm{NO}_{3}{ }^{-}$-ions at pulse plating conditions has strong (002) preferable growth orientation in the c-axis direction. According to [1], increase of (002) reflection in relative intensity is consistent with formation of $\mathrm{ZnO}$ rod crystallites along c-axis. In [2-4, 6] judgment, such preferential growth in the (001) plane results in $1 \mathrm{D}$ nanostructure of $\mathrm{ZnO}$ arrays, e.g. nanowires, nanorods or nanopillars, that grow along the direction perpendicular to the substrate. 


\section{Discussion and Conclusions}

We have determined that for obtaining by electrodeposition of $\mathrm{ZnO}$ arrays preferential grown in the (001) plane it is necessary to diminish adsorption of $\mathrm{Cl}^{-}$-ions and hydrogen beads on this plane.

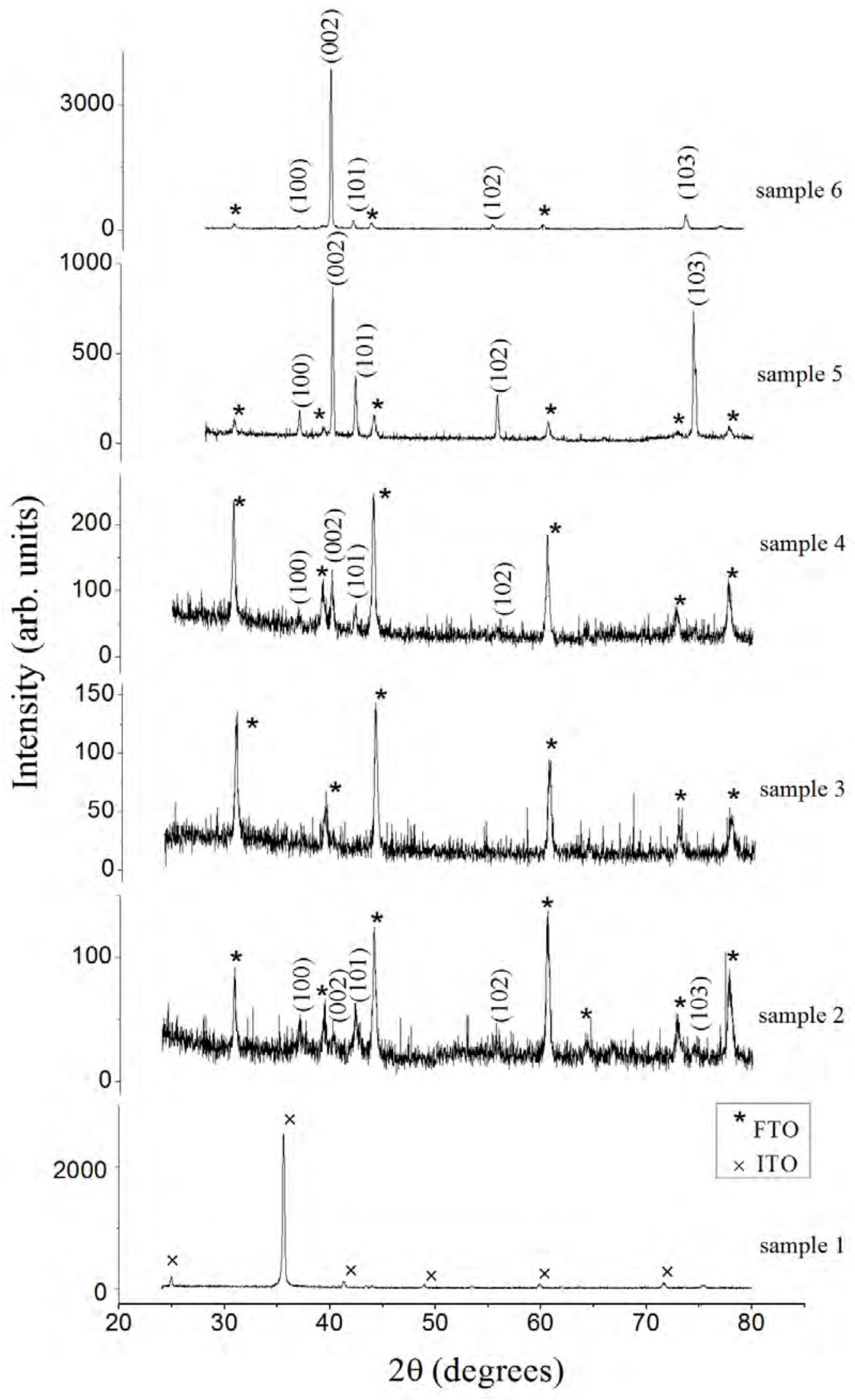


Fig. 2. XRD patterns of $\mathrm{ZnO}$ layers electrodeposited onto transparent conducting oxide coating glass substrates $(*-F T O, \times-I T O)$.

It has been shown that such conditions are created in electrolyte that contains $0.05 \mathrm{M}$ $\mathrm{Zn}\left(\mathrm{NO}_{3}\right)_{2}$ and $0.1 \mathrm{M} \mathrm{NaNO}$ during electrodeposition in pulse plating regime with rectangular impulses of cathode potential (20 ms on-time at $U_{\text {on }}=-1.4 \mathrm{~V}$ and $30 \mathrm{~ms}$ off-time at $U_{\text {off }}=-0.8 \mathrm{~V}$ ) on FTO-coated glass substrates. Therefore, in this work we for the first time have demonstrated the successful growth of $1 \mathrm{D} \mathrm{ZnO}$ nanostructures by pulse plating without using of templates. The obtained $\mathrm{ZnO}$ arrays have to be the suitable layers for solar cells with extra thin absorbers.

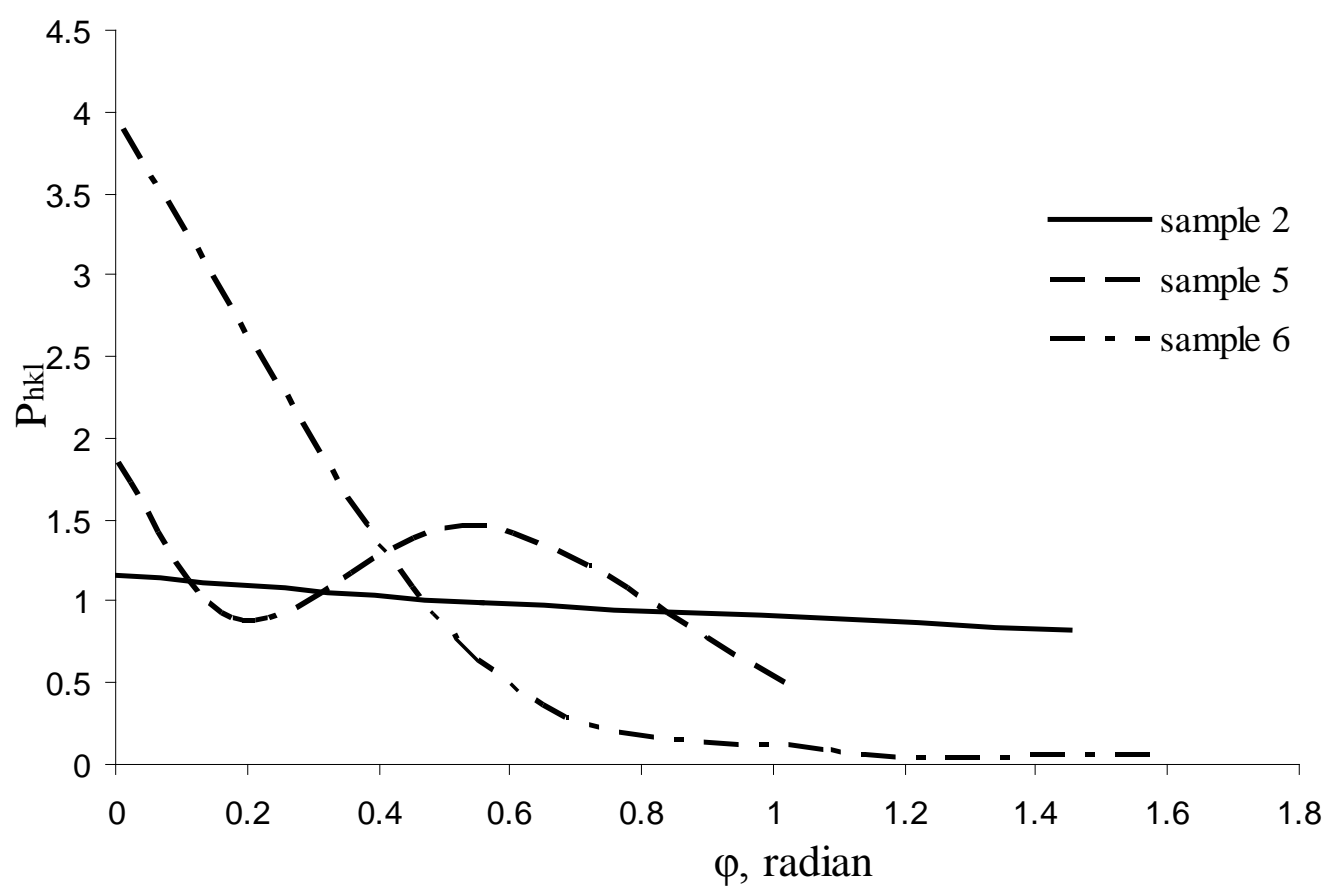

Fig. 3. Degree of texture perfection of electrodeposited $\mathrm{ZnO}$ arrays.

\section{Acknowledgments}

The work was supported by STCU under Project 4301.

\section{References}

[1] K. Govender, D. S. Boyle, P. B. Kenway. P. O’Brein, J. Mater. Chem. 14, 2004, pp. 2575-2591.

[2] C. X. Xu, X. W. Sun, Z. L. Dong, G. P. Zhu, Y. P. Cui, Appl. Phys. Lett. 88, 2006, pp. 093101.

[3] X. Hu, Y. Masuda, T. Ohji, K. Kato, Journal of the Ceramic Society of Japan 116 (3), 2008, pp. 384-388.

[4] D. Pradhan, M. Kumar, Y Ando, K. T. Leung, J. Phys. Chem. C 112, 2008, pp. 70937096.

[5] A.M. Peró, P. Ravirajan, K. Govender, D.S. Boule, P. O’Brein, D. D. C. Bradley, J. Nelson, J. R. Durrant, J. Mater. Chem. 16, 2006, pp. 2088-2096. 
[6] X. Ju, W. Feng, X. Zhang, V. Kittichungchit, T. Hori, H. Moritou, A. Fujii, M. Ozaki, Solar Energy Materials and Solar Cells 93, 2009, pp.1562-1567.

[7] E. Michaelis, D. Wöhrle, J. Rathousky, M. Wark, Thin Solid Films 497, 2006, pp.163169.

[8] D. Pradhan, K. T. Leung, J. Phys. Chem. C 112, 2008, pp. 1357-1374.

[9] Y. Fukunaka, K. Kuribauashi, Space Utiliz. Res. 24, 2008, pp. 27-30.

[10] M. Gupta, D. Pinisetty, J.C. Flake, J. J. Spivey, Journal of the Electrochemical Society 157, 2010, pp. D473-D478.

[11] Structura i phizicheskie svojstva tverdogo tela /edited by L.S. Palatnik, Kiev, Visshaja shkola, 1983, p.284 [in Russian].

[12]A. Malik, B.C. Ray, Thin Solid Films 517, 2009, pp. 6612-6616.

[13]Y. Y. Lurje, Spravochnik po analiticheskoy himiji, Moscow, Himija, 1989, p.448 [in Russian]. 